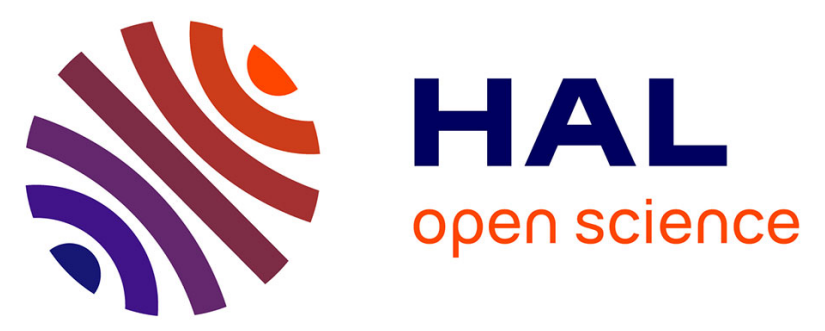

\title{
A doubly responsive probe for the detection of Cys4-tagged proteins
}

\author{
N. Kotera, E. Dubost, G. Milanole, E. Doris, E. Gravel, N. Arhel, Thierry \\ Brotin, J.-P. Dutasta, J. Cochrane, E. Mari, et al.
}

\section{- To cite this version:}

N. Kotera, E. Dubost, G. Milanole, E. Doris, E. Gravel, et al.. A doubly responsive probe for the detection of Cys4-tagged proteins. Chemical Communications, 2015, 5, pp.11482-11484. 10.1039/C5CC04721H . hal-01187782

\section{HAL Id: hal-01187782 \\ https://hal.science/hal-01187782}

Submitted on 17 Nov 2015

HAL is a multi-disciplinary open access archive for the deposit and dissemination of scientific research documents, whether they are published or not. The documents may come from teaching and research institutions in France or abroad, or from public or private research centers.
L'archive ouverte pluridisciplinaire HAL, est destinée au dépôt et à la diffusion de documents scientifiques de niveau recherche, publiés ou non, émanant des établissements d'enseignement et de recherche français ou étrangers, des laboratoires publics ou privés. 


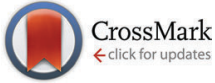

Cite this: Chem. Commun., 2015, 51,11482

Received 8th June 2015,

Accepted 12th June 2015

DOI: $10.1039 / \mathrm{c5cc04721h}$

www.rsc.org/chemcomm

\section{A doubly responsive probe for the detection of Cys4-tagged proteins $\dagger$}

\author{
N. Kotera, $\ddagger^{a}$ E. Dubost, ${ }^{a}$ G. Milanole, ${ }^{a}$ E. Doris, ${ }^{a}$ E. Gravel, ${ }^{a}$ N. Arhel, ${ }^{b}$ T. Brotin, ${ }^{c}$ \\ J.-P. Dutasta, ${ }^{C}$ J. Cochrane, ${ }^{C}$ E. Mari, ${ }^{\text {ad }}$ C. Boutin, ${ }^{d}$ E. Léonce, ${ }^{d}$ P. Berthault ${ }^{d}$ and \\ B. Rousseau*a
}

Recombinant proteins bearing a tag are crucial tools for assessing protein location or function. Small tags such as Cys4 tag (tetracysteine; Cys-Cys-X-X-Cys-Cys) are less likely disrupt protein function in the living cell than green fluorescent protein. Herein we report the first example of the design and synthesis of a dual fluorescence and hyperpolarized ${ }^{129}$ Xe NMR-based sensor of Cys4-tagged proteins. This sensor becomes fluorescent when bound to such Cys4-tagged peptides, and the ${ }^{129} \mathrm{Xe}$ NMR spectrum exhibits a specific signal, characteristic of the biosensor-peptide association.

Noninvasive molecular imaging methods are vital in both biological research and clinical care. In the field of molecular and cellular biology, fluorescence imaging techniques are the most widely used because of their high sensitivity, high spatiotemporal resolution, and simple experimental procedures. Small organic probes with two arsenic moieties capable of interacting selectively with proteins that contain a tetracysteine tag (Cys4 = Cys-Cys-X-X-Cys-Cys where $\mathrm{X}$ is any amino acid except cysteine) were introduced by Roger Tsien and co-workers. ${ }^{1}$ Covalent interaction between the Cys4 tag of recombinant proteins and the biarsenical probe induces a significant increase in fluorescence, allowing the in vitro and in vivo imaging of these

\footnotetext{
${ }^{a}$ iBiTec-S/SCBM, LabEx LERMIT, CEA Saclay, 91191 Gif-sur-Yvette, France. E-mail: bernard.rousseau@cea.fr

${ }^{b}$ Inserm U941, Hôpital St Louis, 1 avenue Claude Vellefaux, 75010 Paris, France

${ }^{c}$ Laboratoire de Chimie, CNRS, Ecole Normale Supérieure de Lyon,

46 Allée d'Italie, 69364 Lyon Cedex 07, France

${ }^{d}$ CEA Saclay, IRAMIS, NIMBE, UMR CEA/CNRS 3685, Laboratoire Structure et Dynamique par Résonance Magnétique, 91191 Gif-sur-Yvette, France

$\dagger$ Electronic supplementary information (ESI) available: Synthetic details and characterization, fluorescence and ${ }^{129} \mathrm{Xe}$ NMR experiments of the compounds. See DOI: $10.1039 / \mathrm{c} 5 \mathrm{cc} 04721 \mathrm{~h}$

¥ Naoko Kotera, Emmanuelle Dubost and Gaëlle Milanole performed the syntheses. Eric Doris, Edmond Gravel and Bernard Rousseau contributed to the compound design. Emilie Mari, Céline Boutin, Estelle Léonce and Patrick Berthault performed the ${ }^{129} \mathrm{Xe}$ NMR spectra. Thierry Brotin, Jean-Pierre Dutasta and James Cochrane perfomed the synthesis of cryptophane hexacarboxylate. Nathalie Arhel and Naoko Kotera were involved in fluorescent experiments. Naoko Kotera, Emmanuelle Dubost, Bernard Rousseau and Patrick Berthault wrote the paper.
}

proteins. Biarsenical probes, FlAsH and $\mathrm{CrAsH}^{2}$ (a carboxy FlAsH derivative), have been used as innovative tools for assessing protein location or function and in vivo fluorescence imaging applications, as they exhibit a low non-specific signal. ${ }^{3}$ However, fluorescence imaging with such probes has a depth of penetration in living tissues of only ca. 1-2 mm.

Furthermore, magnetic resonance imaging (MRI) is one of the most powerful clinical modalities for providing in-depth anatomical and physiological information on tissues. However, it clearly lacks sensitivity. The recent advent of hyperpolarized species can overcome this difficulty, and several nuclear magnetic resonance (NMR) probes produced by dynamic nuclear polarization, para-hydrogen induced polarization or optical pumping have been proposed for the study of biological cells (see for instance ref. 4 for a review). Recently, ${ }^{129}$ Xe NMR-based biosensors made of functionalized molecular cages that possess a biological ligand and can reversibly bind xenon in solution, giving it a specific resonance frequency, have been proposed. ${ }^{5}$ Xenon is a non-toxic gas, soluble in biological fluids, and its nuclear spin can easily be hyperpolarized, leading to an NMR signal enhancement by several orders of magnitude. Such an approach was employed for the design of sensitive $\mathrm{pH}$ - and temperature-reporters, ${ }^{6}$ and for detection of various biological systems, including enzymes, ${ }^{7}$ nucleic acids ${ }^{8}$ and cell surface receptors. ${ }^{9}$ However, for the latter, owing to the subcellular spatial resolution of MRI, distinction of biological phenomena occurring in the cell compartment or outside is not possible. A first approach using bimodal ${ }^{129} \mathrm{Xe}$ NMR-fluorescence probes enabled us and others to reveal the cell uptake of xenon biosensors. ${ }^{9 a, b, g}$ Nevertheless, the ${ }^{129}$ Xe NMR spectra alone did not allow discrimination of the out- and in-cell compartments.

In order to facilitate this assignment task and safely address intracellular events, we propose here a dedicated molecular construct, where both fluorescence and ${ }^{129}$ Xe NMR can be used. It takes advantage of the high diffusivity of xenon, as so far it is the sole hyperpolarized species that has been shown to cross the cell membrane passively while keeping more than $90 \%$ of its hyperpolarization. ${ }^{10}$ The idea behind this approach is to activate both the fluorescence and the NMR response by an 


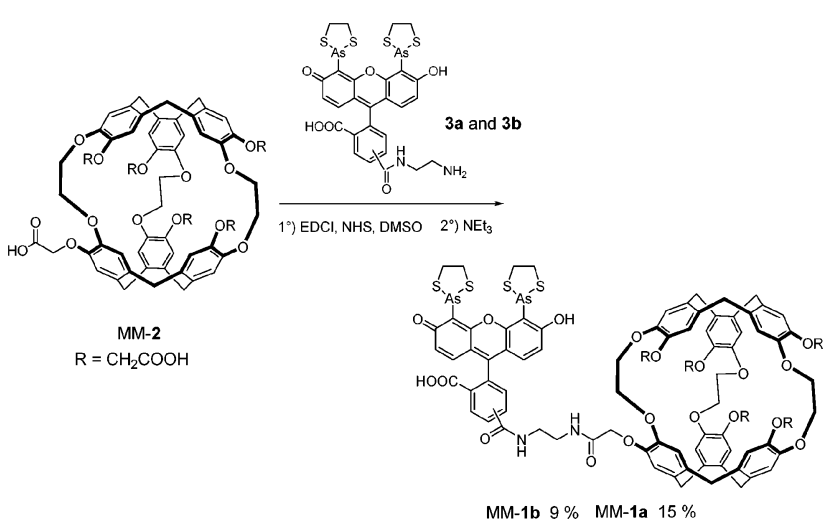

Scheme 1 Chemical structure of cryptophanes $M M-1 \mathbf{a}$ and $M M-\mathbf{1 b}$.

intracellular molecular actuator. The biosensor, designed to detect recombinant Cys4-tagged proteins, is made of a water-soluble cryptophane covalently linked to a CrAsH moiety (see Scheme 1).

The procedure of Ueno et al. ${ }^{11}$ enabled us to obtain two CrAsH derivatives from a mixture of 5-carboxyfluorescein and 6-carboxyfluorescein. These derivatives were then activated in the presence of carbodiimide and $\mathrm{N}$-hydroxysuccinimide and functionalized with an excess of ethylene diamine to afford $\mathbf{3 a}$ and $\mathbf{3 b}$ (Scheme 1 and ESI $\dagger$ ). Since previous investigations have demonstrated that two enantiomers can produce different ${ }^{129} \mathrm{Xe}$ NMR signals upon binding to structures bearing stereogenic centers, ${ }^{12}$ we synthesized separately the two enantiomers $M M-2$ and $P P-2$ by a multi-step procedure from enantiopure cryptophanol-A. ${ }^{13}$ The primary amino group of the CrAsH derivatives $\mathbf{3 a}$ and $\mathbf{3 b}$ was directly coupled to the cryptophane $M M-2$ to form a chemically stable amide linkage. The synthesis led to the formation of two regioisomers $M M-1 \mathbf{a}$ and $M M-1 \mathbf{b}$, which were successfully separated by HPLC with $15 \%$ and $9 \%$ yield, respectively. Compound $M M-1 \mathrm{a}$ is soluble in water at physiological $\mathrm{pH}$ thanks to the presence of the five carboxylic acid moieties attached to the cryptophane backbone. ${ }^{14}$ Previously, the same cryptophane core on which a nitrilotriacetic moiety was grafted, was used for detection of trace amounts of metal cations. ${ }^{12}$ Compound $M M-1 \mathrm{a}$ was further used for fluorescence and NMR experiments.

The affinity of $M M$-1a for a tetracysteine-tag was first tested by fluorescence on the peptide Ace-WEAAAREACCRECCARA-CONH${ }_{2}$, which was the peptide chosen by Tsien et al. ${ }^{1}$ for its propensity to form $\alpha$-helices. Samples with different ratios of this peptide to $M M-1 \mathrm{a}$ were prepared. Fluorescence was then monitored over 4 hours at room temperature at $535 \mathrm{~nm}$ with excitation at $480 \mathrm{~nm}$ (Fig. 1). In the presence of the tagged peptide, fluorescence rapidly increased and stabilized after one hour. Fluorescence drastically increased with increasing amounts of Cys4-tagged peptide. Upon binding of the peptide, the biosensor became 24 times more fluorescent. The same results were obtained with the biosensor in micromolar or millimolar concentrations. Interestingly, without peptide $M M$-1a exhibits a 4.5 times lower fluorescence than single CrAsH moiety (see Fig. S4, ESI $\dagger$ ), which is in favor of our approach.

These results prompted us to evaluate this biosensor for hyperpolarized ${ }^{129}$ Xe NMR applications.

The present ${ }^{129} \mathrm{Xe}$ NMR spectroscopy study was conducted at pH 7 in a phosphate buffer. In the absence of the Cys4-tagged

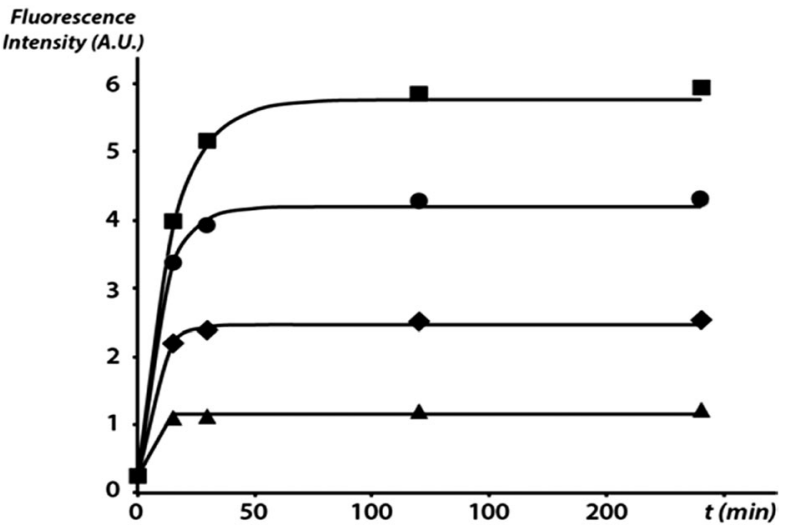

Fig. 1 Fluorescence intensity over time of a $50 \mu \mathrm{M}$ solution of $M M-1 a$ in phosphate buffer with various equivalents of the peptide Ace-WEAAAREA CCRECCARA-CONH (triangles: 0.25 eq.; diamonds: 0.5 eq.; circles: 1 eq.; squares: 2 eq.).

peptide, the ${ }^{129} \mathrm{Xe}$ NMR spectrum of $M M-1 \mathrm{a}$ at $293 \mathrm{~K}$ exhibited two distinct signals: the signal of free xenon in the buffer calibrated at $\delta=196 \mathrm{ppm}$ (not shown) and the signal of encapsulated xenon at $\delta=66.8 \mathrm{ppm}$ (Fig. 2a). The addition of an excess of peptide to $M M-\mathbf{1 a}$ caused the disappearance from the ${ }^{129}$ Xe NMR spectrum of the signal at $66.8 \mathrm{ppm}$ and led to the appearance of a new signal at $\delta=73.2$ ppm (Fig. 2b). This experiment clearly demonstrates the extreme sensitivity of xenon towards its environment.

A more detailed study was then performed using both LC/MS analysis and ${ }^{129} \mathrm{Xe}$ NMR to clarify the interactions between the biosensor and the tagged peptide. Solutions containing the biosensor and increasing amounts of peptide (0 eq., 0.5 eq., 1 eq., and 10 eq.) were prepared and analyzed (Fig. S2, ESI $\dagger$ ). Addition of 0.5 equivalents of peptide to a $25 \mu \mathrm{M}$ solution of $M M$-1a caused the appearance of two new caged xenon signals at 68.4 and $73.2 \mathrm{ppm}$, which were still visible in the mixture containing one equivalent of peptide. For the mixture with 10 eq. peptide, the xenon signals

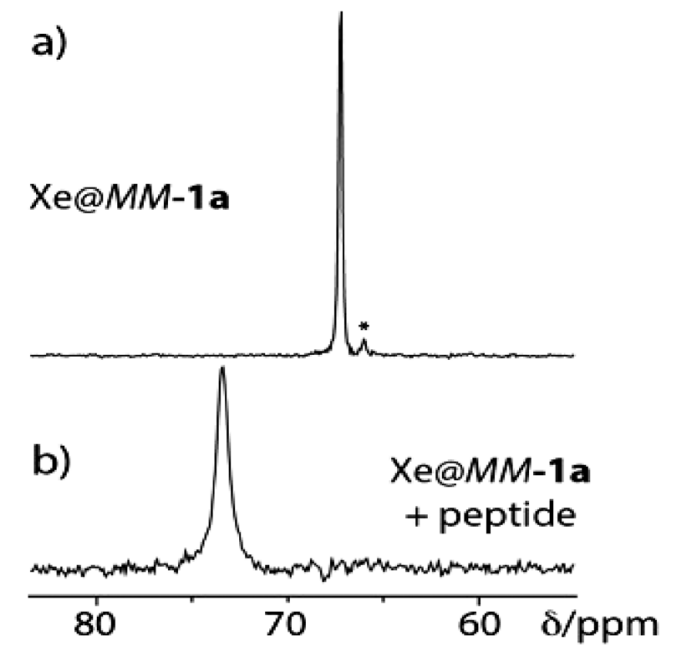

Fig. 2 High field part of the one-scan ${ }^{129} \mathrm{Xe}$ NMR spectrum of a $25 \mu \mathrm{M}$ solution of $M M-1 \mathbf{a}$ in phosphate buffer. (a) $M M-1 \mathbf{a}$ alone; (b) in the presence of 10 equivalents of the peptide. The star denotes residual MM-2. 
at $66.8 \mathrm{ppm}$ and $68.4 \mathrm{ppm}$ had totally disappeared. As mentioned above, the latter signal corresponds to xenon encapsulated in the biosensor when it binds the peptide via the two arsenic atoms. The LC/MS analysis (Fig. S3 of the ESI $\dagger$ ) of this mixture showed unambiguously the presence of covalent complexes between the biosensor and the peptide. We were not able to determine the structure of the intermediate compounds that give the sharp signal at $68.4 \mathrm{ppm}$, but from the ${ }^{129} \mathrm{Xe}$ NMR spectrum some assumptions can be made. The peak at $68.4 \mathrm{ppm}$ could be due to the transient presence of a biosensor attached to the peptide by only one arsenic atom. Its sharpness indicates that caged xenon (and therefore the cage itself) retains sufficient mobility, ${ }^{15}$ which supports our hypothesis. It is unlikely that this signal corresponds to other pairs of arsenic bridges with the cysteines at the residue $i$-residue $i+1$ and $i+4-i+5$ locations instead of the most probable situation of the $i-i+$ 4 and $i+1-i+5$ positions (see Fig. 1 in ref. 1 ). If such forms exist, they would rather contribute to the broadening of the signal at $73.3 \mathrm{ppm}$. The addition of two equivalents of peptide enables the complete formation of the complex involving two arsenic atoms as confirmed by fluorescence, while adding 10 eq. of peptide no longer affects the NMR signal.

In conclusion, we have described the synthesis of a smart biosensor with dual properties. The enantiopure biosensor $M M-1 \mathrm{a}$ exhibits a strong fluorescence signal as well as a ${ }^{129}$ Xe NMR signal highly specific for caged xenon and different from that of the free biosensor, when bound to the tetracysteine-tagged peptide. The current challenge in cryptophane chemistry is the design and synthesis of smart biosensors that present a net change in frequency for encapsulated xenon in the presence of the target and therefore allow a further gain in sensitivity, even in low or inhomogeneous magnetic fields such as those encountered in in vivo MRI. The observed difference of $6.4 \mathrm{ppm}$ between the signals of encapsulated xenon in the absence and presence of peptide is sufficient for spectroscopic MRI or in vitro and even in vivo localized spectroscopy. Recent approaches such as ${ }^{129} \mathrm{Xe}$ UltraFast Z-spectroscopy, which very efficiently detects trace concentrations of biosensors, have already shown that distinction between the two signals is still accessible with such a frequency difference. ${ }^{16}$

After the recent publications showing that xenon and cryptophane derivatives penetrate cells and allow in-cell ${ }^{129} \mathrm{Xe} \mathrm{NMR},{ }^{9}$ the capacity of these types of sensors to detect intracellular tetracysteinetagged proteins will now be assessed.

Supports from the French Ministry of Research (project ANR-12-BSV5-0003), from the Fondation pour la Recherche Médicale (project DCM20111223065) and from INSERM (convention \#PC201326) are acknowledged.

\section{Notes and references}

1 (a) B. A. Griffin, S. R. Adams and R. Y. Tsien, Science, 1998, 281, 269-272; (b) S. R. Adams, R. E. Campbell, L. A. Gross, B. R. Martin,
G. K. Walkup, Y. Yao, J. Llopis and R. Y. Tsien, J. Am. Chem. Soc., 2002, 124, 6063-6076.

2 H. Cao, B. Chen, T. C. Squier and M. U. Mayer, Chem. Commun., 2006, 2601-2603.

3 (a) Y. Xiong, B. Chen, L. Shi, J. K. Fredrickson, D. J. Bigelow and T. C. Squier, Biochemistry, 2011, 50, 9738-9751; (b) B. N. G. Giepmans, S. R. Adams, M. H. Ellisman and R. Y. Tsien, Science, 2006, 312, 217-224; (c) C. Hoffmann, G. Gaietta, M. Bünemann, S. R. Adams, S. OberdorffMaass, B. Behr, J.-P. Vilardaga, R. Y. Tsien, M. H. Ellisman and M. J. Lohse, Nat. Methods, 2005, 2, 171-176.

4 M. H. Lerche, P. R. Jensen, M. Karlsson and S. Meier, Anal. Chem., 2015, 87, 119-132.

5 (a) M. M. Spence, S. M. Rubin, I. E. Dimitrov, E. J. Ruiz, D. E. Wemmer, A. Pines, S. Qin Yao, F. Tian and P. G. Schultz, Proc. Natl. Acad. Sci. U. S. A., 2001, 98, 10654-10657; (b) P. Berthault, G. Huber and H. Desvaux, Prog. Nucl. Magn. Reson. Spectrosc., 2009, 55, 35-60.

6 (a) P. Berthault, H. Desvaux, T. Wendlinger, M. Gyejacquot, A. Stopin, T. Brotin, J.-P. Dutasta and Y. Boulard, Chem. - Eur. J., 2010, 16, 12941-12946; (b) B. A. Riggle, Y. Wang and I. J. dmochowski, J. Am. Chem. Soc., 2015, 137, 5542-5548; (c) L. Schröder, L. Chavez, T. Meldrum, M. Smith, T. J. Lowery, D. E. Wemmer and A. Pines, Angew. Chem., Int. Ed., 2008, 47, 4316-4320.

7 (a) Q. Wei, G. K. Seward, P. A. Hill, B. Patton, I. E. Dimitrov, N. N. Kuzma and I. J. Dmochowski, J. Am. Chem. Soc., 2006, 128, 13274-13283; (b) J. A. Aaron, J. M. Chambers, K. M. Jude, L. Di Costanzo, I. J. Dmochowski and D. W. Christianson, J. Am. Chem. Soc., 2008, 130, 6942-6943; (c) J. M. Chambers, P. A. Hill, J. A. Aaron, Z. Han, D. W. Christianson, N. N. Kuzma and I. J. Dmochowski, J. Am. Chem. Soc., 2009, 131, 563-569.

8 V. Roy, T. Brotin, J.-P. Dutasta, M.-H. Charles, T. Delair, F. Mallet, G. Huber, H. Desvaux, Y. Boulard and P. Berthault, ChemPhysChem, 2007, 8, 2082-2085.

9 (a) C. Boutin, A. Stopin, F. Lenda, T. Brotin, J.-P. Dutasta, N. Jamin, A. Sanson, Y. Boulard, F. Leteurtre, G. Huber, A. Bogaert-Buchmann, N. Tassali, H. Desvaux, M. Carrière and P. Berthault, Bioorg. Med. Chem., 2011, 19, 4135-4143; (b) S. Klippel, J. Döpfert, J. Jayapaul, M. Kunth, F. Rossella, M. Schnurr, C. Witte, C. Freund and L. Schröder, Angew. Chem., Int. Ed., 2014, 53, 493-496; (c) F. Rossella, H. M. Rose, C. Witte, J. Jayapaul and L. Schröder, ChemPlusChem, 2014, 79, 1463-1471; (d) H. M. Rose, C. Witte, F. Rossella, S. Klippel, C. Freund and L. Schröder, Proc. Natl. Acad. Sci. U. S. A., 2014, 111, 11697-11702; (e) G. K. Seward, Q. Wei and I. J. Dmochowski, Bioconjugate Chem., 2008, 19, 2129-2135; $(f)$ G. K. Seward, Y. Bai, N. S. Khan and I. J. Dmochowski, Chem. Sci., 2011, 2, 1103-1110; ( $g$ ) N. S. Khan, B. A. Riggle, G. K. Seward, Y. Bai and I. J. Dmochowski, Bioconjugate Chem., 2015, 26, 101-109.

10 C. Boutin, H. Desvaux, M. Carrière, F. Leteurtre, N. Jamin, Y. Boulard and P. Berthault, NMR Biomed., 2011, 24, 1264-1269.

11 Y. Ueno, G.-S. Jiao and K. Burgess, Synthesis, 2004, 2591-2593.

12 (a) N. Kotera, N. Tassali, E. Léonce, C. Boutin, P. Berthault, T. Brotin, J.-P. Dutasta, L. Delacour, T. Traoré, D.-A. Buisson, F. Taran, S. Coudert and B. Rousseau, Angew. Chem., Int. Ed., 2012, 51, 4100-4103; (b) N. Tassali, N. Kotera, C. Boutin, E. Léonce, Y. Boulard, B. Rousseau, E. Dubost, F. Taran, T. Brotin, J.-P. Dutasta and P. Berthault, Anal. Chem., 2014, 86, 1783-1788.

13 A. Bouchet, T. Brotin, M. Linares, D. Cavagnat and T. Buffeteau, J. Org. Chem., 2011, 76, 7816-7825.

14 G. Huber, T. Brotin, L. Dubois, H. Desvaux, J.-P. Dutasta and P. Berthault, J. Am. Chem. Soc., 2006, 128, 6239-6246.

15 T. J. Lowery, S. Garcia, L. Chavez, E. J. Ruiz, T. Wu, T. Brotin, J.-P. Dutasta, D. S. King, P. G. Schultz, A. Pines and D. E. Wemmer, ChemBioChem, 2006, 7, 65-73.

16 (a) C. Boutin, E. Léonce, T. Brotin, A. Jerschow and P. Berthault, J. Phys. Chem. Lett., 2013, 4, 4172-4176; (b) J. Döpfert, C. Witte and L. Schröder, ChemPhysChem, 2014, 15, 261-264; (c) J. Döpfert, M. Zaiss, C. Witte and L. Schröder, J. Magn. Reson., 2014, 243, 47-53. 